\title{
Naturalness in Translating The Jakarta Post Article by Students of English Department of Widya Gama Mahakam University
}

\author{
Widi Syahtia Pane ${ }^{1}$, Dedi Rahman Nur ${ }^{2}$, Abdul Rohman ${ }^{3}$ \\ \{widi.pane@gmail.com¹ ${ }^{1}$ d.blues84@gmail.com ${ }^{2}$,rohmanuwgm@gmail.com ${ }^{3}$ \} \\ ${ }^{1,2,3}$ University of Widya Gama Mahakam, J1. K. H. Wahid Hasyim No. 28 Samarinda, East Borneo,
}

\begin{abstract}
Translation is one of the important thing in learning English, therefore in this study, the purpose were to know the kinds of error and the kinds of error that was mostly made by the sixth semester students of English Department of Widya Gama Mahakam University in translating a news article. The design of the study was explanatory research and the method of this study was mixed method. The sample of this study was $70 \%$ from population of sixth semester students of English Department of Widya Gama Mahakam University. Data collection technique was simple random sampling. Data analyzing technique was 6 steps of data analysis stated by Creswell (1984; 154-158). According to error analysis of naturalness in translating The Jakarta Post post article by sixth semester students of English Department of Widya Gama Mahakam in academic year 2018/2019, the result of this study was the students committed all of kinds of error from level of naturalness in translation. The kind of error mostly made by the sixth semester students of English Department of Widya Gama Mahakam University in translating a news article was Cognate Word $(72.5 \%, 95$ errors). While the rest of the errors were made by Sentence Structure (15 errors, 11.5\%), Other 'obvious' Area of Interference (8 errors, $6.2 \%)$, Word Order (7 errors, 5.3\%), The Using of Gerund, Infinitive, Verb-Noun and Affix (6 errors, $4.5 \%)$, and there was no students who committed Old-fashioned error ( 0 errors, $0 \%)$.
\end{abstract}

Keywords: Translation, Naturalness, The Jakarta Post Article

\section{Introduction}

Translation is a craft consisting in the attempt to replace a written message and/or statement in another language by the same message and/or statement in another language, Newmark [14]. Translating is the deed to translate a form of language into another language. The person who translate the Source Language (SL) into Target Language (TL) is called translator (for the written language) or interpreter (for spoken language). Translation also means changing a written or spoken source language to the target language, i.e from French to English, English to Bahasa Indonesia, Bahasa Indonesia to Japanese, etc. In translating the SL the translator or interpreter is able to translate the translation by word-to-word way if the sentence is contained a simple meaning or even a single word only, but they have to be more careful to choose a proper meaning of the single word from the SL, because in a language, there are many words that have more than one meaning. The translator and interpreter have to 
know the context and what the word wants. Same as in phrase, sentence, paragraph and a text which contains many words, they have to be more careful to translate it. The translators cannot translate by the bilingual dictionary only, sometimes they need to know the term of idiomatic expression and use idiomatic dictionary as well and pay so much attention to the diction - the word that is chosen to contrive the right ones or to the word that is nearer with the source language words' means.

In the translating matter, there are some criteria of the good translation which are accuracy, clarity and naturalness. Based on Barnwell [3], accuracy is a comprehension of the message and reformatting the the meaning of message as accurate as possible in target language. Clarity here means some ways to express an idea-choose other expressions clearly; the way which is understood by common people. Naturalness in order to the translation is effective and accepted; it needs to use a natural target language, the language that has already been changed into target language should not be odd.

Naturalness in translation was the focus of this study. It is one of the criteria of good translation according to Barnwell [3]. The naturalness means the words of translation is natural in target language words. The translation will be easier to be comprehended if the translator/interpreter uses the natural words. Priono [19] adds There is close connection between accuracy and naturalness. Accuracy is a right way, but naturalness is important in giving a casual sense. Accurate translation sometimes uses the meaning which is uncommon by some people, but it is right. Naturalness is important to make or change those uncommon words with other same meaning word (synonyms) in common words to be easily understood by all of the people in target language. In other way, it is stated that, natural translation uses communicative language which is accepted in target language.

The writer chose an article entitled "KPK investigators Attacked while on Duty" from The Jakarta Post because of some reasons-First, the article informs the actual national issue that become public's attention which recently happened that day, so by reading this article, the writer wanted the subject would get the new information about this issue or would know what's happened out there-for those who did not know this topic at all. Second, the level of difficulty of this English article was suitable for the eighth semester students; it was not too difficult nor too easy. The last, regarding to the content and the difficulty of the news article, there would be possibility for the students to make some errors of translating in natural way, whether in word order error, common structure error, appropriateness of gerunds, infinitives, verb-nouns error, and old-fashioned error, Barnwell [3]. Therefore, the researchers would analyze the errors that students made in in translating this article and described it in order to reveal the problems of this study. From that reasons, the writer expects she would reveal the error of translating an English news article from The Jakarta Post in natural way by the sixth semester students of English Department of Widya Gama Mahakam University in academic year 2018/2019 and described them into this research.

\section{Review of Related Literature}

\subsection{Concept of Translation}

The definition of translation has been stated differently by the different experts. There are many definitions about translation as the different writers define it in different way. Sarvory [22] says translation is made possible by an equivalence of thought that lies behind its different verbal expression. According to Nida [16] translation consist in reproducing in the 
receptor language the closest natural equivalent of the source language message, first in terms of meaning and secondly in terms of style. Larson [9] states that translation consist of studying lexicon, grammatical structure, communication situation and cultural context of the source language, analyzing in order to determine its meaning, the reconstructing the same meaning using the lexicon and grammatical structure which appropriate in the receptor language and its cultural context.

\subsection{Criteria of Good Translation}

Larson [9] suggests that the ideal translation should be (a) accurate, in that, it reproduces as exactly as possible from the meaning of the source text. (b) Natural, in that, it uses natural forms of the receptor language in a way that is appropriate to the kind of the text being translated, and communicative-expresses all the aspects of the meaning in a way that is readily understandable to intended the audience.

According to sil.org, translation should be: (1) accurate: representing the meaning of the source text as faithfully as possible. (2) natural: using the receptor language in ways appropriate to the text being translated. (3) Communicative: expressing the meaning in an understandable way to the intended audience.

Barnwell [3] states that a good translation should have (a) accuracy: a comprehension of the exact source language message and reformatting the meaning of the message as accurate as possible in target language. (b) Clarity: the way which is understood common people. (c) naturalness: to make the translation is effective and accepted, it needs to use a natural target language. The translation should not be odd. Based on the theories above, it can be concluded that the criteria of the good translation should be clear, accurate, natural and communicative. Clear means, the translation should be comprehended by common people. Accurate means translation should be translated as exact as the source language. Communicative means the translation can be understood by the audience. Naturalness means the translation should be appropriate and effective in target language so it will seem and sound natural.

\subsection{Concept of Naturalness in Translation}

Naturalness is one of the aspects of the good translation. All through the history of translation study, the concept of naturalness has been changed by different definition; Newmark [14] refers to natural language as one constructed from the "most frequently used structures and words" or "the common grammar, idioms and words that meet that kind of situation." For him (Newmark, [14]) it is a fluent language which might be marred by adherence to the source language (SL) norms, and yet should not be misinterpreted as being ordinary language.

Nida [16] regards the concept as parallel to dynamic equivalence and thus defines translation grounded on such equivalence as "the closest natural equivalent to the sourcelanguage message." Nida an Taber [15] Elaborate on the concept, they attach it to certain areas: the receptor language and the culture, the context of the message and the target receptors.

Based on the explanation above, the researchers conclude that the natural translation means the translation should be equivalent and has the same message as the SL text, but it should be easy to be understood as simple as possible. To determine a translation as the natural translation, Newmark [14] states that if we wanted to know the naturalness of translation, we had to pay special attention to:

\section{a. Word Order}

In all languages, adverbs and adverbials are the most mobile components of a sentence, and their placing often indicates the degree of emphasis on what is the new information (rheme) as well as naturalness. They are the most delicate indicator of naturalness: 
- He regularly sees me on Tuesday. (Stress on 'regularly')

- He sees regularly on Tuesday. (No stress)

- On Tuesday he sees me regularly. (Stress on 'Tuesday')

b. Common Structure

Common structure can be made unnatural by silly one-to-one translation from any language, it cannot be translated one-to-one or literally translated.

- Lit: This is pen my.

English: 'This is my pen.'

- Lit: I live in city beautiful.

English: 'I live in a clean city.'

Indonesian: 'Ini pena saya.'

Indonesian: 'Saya tinggal di kota bersih.'

c. Cognate Words

Many words sound natural when we transfer them, and may still have the wrong meaning. The causes are varied, but one of them might be because one word that has more than one meaning. It is called Cognate Word. Sometimes it has many similarities in different languages because they come from the same root, as Colorin Colorado [30] states that Cognates are words in two languages that share a similar meaning, spelling, and pronunciation. Many more sound odd when you transfer them, and wrong 'Judging by numbers alone,...' translated into 'Menghakimi dari nomer-nomer sendiri, ...' whereas it sounds natural if the translation is 'Mempertimbangkan dari jumlah saja, ...'

d. The appropriateness of gerunds, infinitives, affix.

The terms gerund and infinitive are found in English only. A gerund is a noun made from a verb by adding '-ing.' The gerund form of the verb 'read' is reading.' Gerund can be used as the subject, the complement, or the object of a sentence. Infinitives are the 'to' form of the verb. The infinitive form of 'read' is 'to read'. Affix term is existed in both English and Bahasa Indonesia. According to Wikipedia, affix is a morpheme that is attached to a word stem to form a new word. Affixes may be derivational, like English -ness and pre- etc, In Bahasa it is called imbuhan, e.g: di-, ter-, -an, etc. The word 'forced' in sentence 'Ukraira is forced to' is translated as 'terpaksa' instead of 'memaksa' because it is passive voice, not past tense.

\section{e. Old-fashioned}

Lexically, perharps the most common symptom of unnaturalness is slightly old-fashioned, now rather 'refined', or 'elevated' usage of words and idioms possibily originating in bilingual dictionaries, e.g in Bahasa Indonesia: Sebagaimana (Seperti), Bilamana (Jika), etc.

f. Other obvious areas

Other obvious areas of interference and therefore unnaturalness lies in the use of the articles; progressive tense; noun compounding; collocations; the currency of idioms or metaphors; aspectual features of verbs; infinitives.

This study is emphasized in error of naturalness in translation instead of other criteria of good translation because to conduct the good translation accurate, clear and communicative are not enough. The translation need to be natural too. Without naturalness in translation, the translated message will sound odd and unusual. Naturalness is important to make or change those uncommon words with other same meaning word (synonyms) in common words to be easily understood by all of the people in target language. 


\section{Method}

The researchers used an explanatory research in this study. According to Maxwell and Mittapalli [12] the term explanatory research implies that the research in question is intended to explain, rather than simply to describe, the phenomena studied. The researchers used mixed method to conduct this study. According to Creswell \& Plano [5]mixed method design is mixed method study where the use quantitative and qualitative method is predetermined and start of research process, and the procedures are implemented as planned. The population in this study was the sixth semester students of English Department of Widya Gama Mahakam University in academic year 2018/2019. There were 31 active students from two classes as population, $70 \%$ of them were taken as the sample by random sampling method.

Data and the source of data of this study was a news article from The Jakarta Post. The title of the article was "KPK Investigators Attacked while on Duty". The sample translated the news article as natural as they can during one hour and 30 minutes. To conduct the analysis, the researchers used 6 steps of data analysis stated by Creswell \& Plano (2011) as follow: (1) Organize and prepare the data. (2) Read through all the data. (3) Begin detailed analysis with a coding process. (4) Generate codes for the description. (5) Advance how the description will be represented in the qualitative research. (6) make an interpretation or meaning of the data.

\subsection{Organize and Prepare the Data.}

This involves transcribing interviews, optically scanning material, typing up field notes, or sorting and arranging the data into different types depending on the sources of information. In this study the researchers collected all of the data from the sample which is the translation result. The data were not re-typed because it was analyzed in the original text the sample would have made.

\subsection{Read Through all the Data.}

To find out the errors that the sample made in natural translation in translating news article, the researchers read the whole data carefully.

\subsection{Begin Detailed Analysis with a Coding Process.}

A code in qualitative inquiry is most often a word or short phrase that symbolically assigns a summative, salient, essence-capturing, and/ or evocative attribute for a portion of language-based or visual data (Saldana, [21]). It involves taking text data or pictures, segmenting sentences (or paragraphs) or images into categories, and labeling those categories with a term. In this study of analyzing the error of naturalness in translating news article, the researchers analyzed the data by giving some codes and marking different highlight color for each error of natural translating.

\subsection{Generate Codes for the Description.}

After reading and finding the whole error in natural translating in translation result, the researchers generated the codes in some categories of error translation in natural way. There are six categories of the error of naturalness in translating based on Newmark's level of translation as the method of analysis - the 'Level' here means 'kind', has no relation with degree or order. The points of this method were explained as bellow:
a. Word order analyzing.
b. Sentence structure analyzing.
c. Cognate word analyzing.
d. The appropriate using of gerund, infinitive, and verb-nouns analyzing.
e. Old-fashioned expression analyzing. 
f. Other obvious areas of interference analyzing (the use of articles, progressive tenses, noun-compounding, collocations, currency of idioms and metaphors, aspectual features of verbs, etc).

In order to find out the errors properly, the researchers generated the codes for each category and subcategory of error as bellows:

Category: Error of Naturalness in Translating

- Subcategory 1: Word Order, Code: WO (Word Order)

- Subcategory 2: Sentence structure analyzing, Code: SS (Sentence Structure)

- Subcategory 3: Cognate word analyzing, Code: Le (Lexis)

- Subcategory 4: The appropriate using of gerund, infinitive, and verb-nouns analyzing, Code: Gr (Gerund), In (Infinitive), V-N (Verb-Nouns), Af (Affix)

- Subcategory 5: Old-fashioned expression analyzing, Code: OF (Old-Fashioned)

- Subcategory 6: Other obvious areas of interference analyzing, Code: Id (Idiom), Co (Collocation), Ar (Article), OT (Other)

\subsection{Advance How the Description will be Represented in the Qualitative research.}

The most popular approach is to use the table to convey the findings of the analysis. This will mention the whole error analysis and the categories in one table to simplify the analysis before making the interpretation. Then to analyze the error that was mostly made by the sample, the researchers used the formula stated by Walsh in Winarno (2003:20):

\subsection{Make an Interpretation or Meaning of the Data.}

$$
\mathrm{Pe}=\frac{\mathrm{n}}{\sum \mathrm{n}} \times 100 \%
$$

A final step in data analysis involves making an interpretation or meaning of the data. This step would be the researchers's personal interpretation about the analysis that has already been put in the table and formula. By this interpretation, we can see what kind of errors that the sample made in translating the news article and which errors type that mostly committed by the sample.

\section{Findings and Discussion}

\subsection{Findings}

This study is emphasized in error of naturalness in translation instead of other criteria of good translation because to conduct the good translation accurate, clear and communicative are not enough. The translation needs to be natural too. Newmark [14] refers to natural language as one constructed from the "most frequently used structures and words" or "the common grammar, idioms and words that meet that kind of situation." For him [14] it is a fluent language which might be marred by adherence to the source language (SL) norms, and yet should not be misinterpreted as being ordinary language. Therefore, in this study, the researchers use the six categories of the error of naturalness in translating based on Newmark's level of translation as the method of analysis.

After collecting all of the translated text from the sample, the researchers herself did a careful reading to analyze the translated text one by one in order to determine the errors that the students made from the translated text of the news article and then generated the whole of errors into six Levels of Naturalness based on Newmark's [14] theory. After that the researchers put the data in a table to make it easier to be comprehended. The table consists of the six of Newmark's Levels of Naturalness and the frequency of the errors that students made 
in translating The Jakarta Post news article as well as the percentage of frequency. As the addition, there is information about the number of students who committed the certain errors.

Table 1. Frequency of Errors in Level of Naturalness' Points

\begin{tabular}{|l|l|l|l|l|}
\hline No & \multicolumn{1}{|c|}{ Level of Naturalness' Points } & $\begin{array}{c}\text { Number of } \\
\text { students }\end{array}$ & \multicolumn{1}{|c|}{ Frequency } & $\begin{array}{c}\text { Percentage of } \\
\text { frequency }\end{array}$ \\
\hline 1 & Word Order error & 6 & 7 & $5.3 \%$ \\
\hline 2 & Sentence Structure error & 9 & 15 & $11.5 \%$ \\
\hline 3 & Cognate Words error & 21 & 95 & $72.5 \%$ \\
\hline 4 & $\begin{array}{l}\text { The using of Gerund, infinitive, } \\
\text { Verb-Noun and affix error }\end{array}$ & 6 & 6 & $4.5 \%$ \\
\hline 5 & Old-Fashioned error & 0 & 0 & $0 \%$ \\
\hline 6 & Other error & 8 & 8 & $6.2 \%$ \\
\hline & & 131 & $100 \%$ \\
\hline
\end{tabular}

Based on the analysis of the data, the researchers found that the sample made errors from some level of naturalness of translation stated by Newmark [14], they were Word Order, Sentence Structure, Cognate Word, The Using of Gerund, Infinitive, Verb-Noun and Affix, and Other 'obvious' Area of Interference, therefore there was no students who made Oldfashioned error in this study. The error that mostly made by the sample was Cognate Word with 95 errors. The percentage of this kind of error was $72.5 \%$, committed by 21 person-the whole of the sample. The next of the most frequents error was from the Sentence Structure. There were 15 errors from this kind of error, meant $11.5 \%$ in percentage, made by 9 students. The third was from Other 'obvious' Area of Interference, it had 8 errors, the percentage of error was $6.2 \%$ of all. This error was made by eight students. The fourth was Word Order. There were 7 errors of it, the percentage was $5.3 \%$ and made by 6 students. The fifth was Using of Gerund, Infinitive, Verb-Noun and Affix, there were 6 errors made by 6 students, and the percentage of frequency was $4.5 \%$. Meanwhile there was no students did error in Oldfashioned level.

In the matter of Cognate Word, the students actually, frequently used the diction or lexis that is still acceptable in term of literal meaning. In this case, translating by dictionary meaning only is not enough. The diction chosen should be more natural to fit-in with the criteria of the good translation. For example, most of students who committed error in Cognate Word, translated the word "investigators" as "Peneliti" or "penyelidik". The word "peneliti" seems quite far for this context, although for dictionary meaning it could be correct. Meanwhile for "penyelidik", the word "investigator" could be correct in term of literal as well as for this context meaning since their job is to investigate (menyelidiki) something, but as for KPK investigators, the word "penyidik" is the most natural and commonly used for this context.

In Sentence Structure, the case of error is illustrated by one of common mistake made by students as an example follows; students often get confused in the last part of the first paragraph of the text; "...has revealed". The perfect tense that should be translated as "(telah) mengungkapkan" translated as "telah terungkap" or telah "diungkap" by most of students who committed this error. They got mistake by misunderstanding the tense as passive voice because both tense use verb three to buid sentence.

In the Other 'obvious' Area of Interference, the causes of this error were varied, such as students still lacked of understanding the meaning of the text. One of students added the word "tidak" ("not") to a sentence when the sentence is not in negative form nor having negative 
meaning. It was very dangerous since the meaning is opposite. The next example is when the students did not write a useful word (omitted a useful word) which is the opposite of the previous example; “....assaulted two on-duty KPK investigators.” Is translated as “..menyerang dua KPK yang bertugas..." the word "investigators" was not translated.

Meanwhile in Word Order error, the error mostly lied on the part "violent crimes subdirectorate" that was translated as "kekerasan kriminal subdirektorat" by some of them instead of "subdirektorat kekerasan kriminal" or "subdirektorat kejahatan dan kekerasan" for more equivalent to the real meaning.

For the using of Gerund, infinitive, Verb-Noun and affix error, the most commited error was in the level of affix error. The examples are mentioned as follows; "the assault" translated as "penyerang" (=assailant) when it should be "penyerangan", "investigators" translated as "diinvestigasi" (=investigated) while it shoul be "penyidik"- the people who conduct investigation, "attacked" translated as "menyerang" when it should be "diserang", etc.

\subsection{Discussion}

According to the interpretation about the error analysis of naturalness in translating a news article, the most frequent error was Cognate Word. Cognate Word means that one word that has more than one meaning, sometimes it has many similarity in different languages because they come from the same root, as Colorin Colorado [30] states that Cognates are words in two languages that share a similar meaning, spelling, and pronunciation. While English may share very few cognates with a language like Chinese, 30-40\% of all words in English have a related word in Spanish. For Spanish-speaking ELLs, cognates are an obvious bridge to the English language. Therefore, the researchers assumed that the cognate word became the most frequent error because English shares very few cognate in Bahasa Indonesia, so the English Learners from Indonesia will find a little bit harder in choosing the right word than the learners that the mother language shares more cognate word. Beside, the researchers assumed that another cause of Cognate Error was the students still lacked of vocabulary. If they had richer vocabulary, the lexis that they chose can be more natural in the target language, because in some cases, there were many words that have more than one meaning. As the translator, they should choose the most suitable one as the translated word to make the more natural translation.

As the students made some errors in Word Order, Sentence Structure and Using of Gerund, Infinitive, Verb-Noun and Affix, the errors were existed because they had weakness of knowledge in grammar. Learning grammar sometimes sounds very traditional for English learning, but for translation, especially the formal tor semi-formal translation text, it is very important and crucial to master grammar as Xin [27] states it is extremely important that these translations are correct lexically and grammatically. When they fail to understand the structure of a sentence, or phrase, or clause, or even a single word, the translated text will be error. If the students master the grammar more significantly, they would conduct the proper translation regarding to Word Order, Sentence Structure and Using of Gerund, Infinitive, Verb-Noun and Affix points.

The Old-fashioned point was the kind of error that students did not commit in this research. Same as the study conducted by Priono [19] -the Old-fashioned point was the least committed error in his research. It might be caused by the language that students' have today. They were accustomed with the modern and casual language in their daily conversation, so rather than making the old-fashioned language, it will be easier for them creating the casual/modern formal style of language in the translated text in this study. 


\section{Conclusions}

Based on the findings, the researchers concluded that the students committed five out of the six kinds of error from level of naturalness in translation based on Newmark [14]. The kind of error mostly made by the eighth semester students of English Department of Widya Gama Mahakam University in translating a news was Cognate Word (72.5\%, 95 errors). The next most frequent errors was Sentence Structure (15 errors, 11.5\%), following by Other 'obvious' Area of Interference ( 8 errors, 6.2\%), Word Order ( 7 errors, 5.3\%), The Using of Gerund, Infinitive, Verb-Noun and Affix (6 errors, $4.5 \%$ ), and there was no students who committed Old-fashioned error (0 errors, $0 \%)$.

The most frequent errors in this study was Cognate Word, it was about lexical choosing. The students need to extensively enrich their vocabulary by reading all of kind of source as news article, books, novel, poems, etc and try to search the meaning of the new vocabulary that they find from those sources. Therefore, they will understand what is the exactly meaning of a word and what are the other meaning of it, because one word can have more than one meaning and the translator should choose the most suitable word in the target language, so that the translated text will sound natural and be equal as the source language.

The other point that should be concerned from the error are Word Order, Sentence Structure and The Using of Gerund, Infinitive, Verb-Noun and Affix. They are related to the grammar. Student with good ability of grammar will understand and translate the text very well. Teacher needs to give extensive lesson more exercises about grammar because it is really important both for creating the self-comprehension about the source text and making the comprehensive interpretation in translated text by conducting the proper sentence structure in the target language.

It would be the teacher, the parents and for those who care about the English learning development's responsibility to motivating and encourage student's interest in translation, therefore giving the task and more lesson about translation will be some of the way to make the students improve their translation ability.

There is no perfect research and this study is also far from perfection. However it can be improved, so the future researchers who will continue this study is expected to improve the study by conducting more accurate method and instrument.

\section{References}

[1] Ary, Donald., Jacobs, Lucy Cheser., \& Razavieh, Asghar. Introduction to Research in Education. USA: The Wadsworth Group. (2002).

[2] Barnwell, Katharine. Bible translation: An introductory course in basic translation principles.3d ed. Dallas: SIL. (1986).

[3] Barnwell, Katharine. Introduction to Semantics and Translation. New York: Summer Institute of Linguistics. (1984).

[4] Bogdan, R.C., \& Biklen, S.K. Qualitative Research for Education: An Introduction to Theory and Methods. Boston: Allyn and Bacon. (1992).

[5] Creswell, J. W., \& Plano Clark, V. L. Designing and conducting mixed methods research (2nd ed.). Thousand Oaks, CA: Sage Publications, Inc. (2011).

[6] J. C. Catford. A Linguistic Theory of Translation: An Essay in Applied Linguistics. Oxford University Press page 20. (1969)

[7] Johan, A. Gani. Reading and Translation. Yogyakarta: Pustaka Belajar. (1996).

[8] Larsen, Iver. The Fourth Criterion of a Good Translation. Dallas: SIL. (2001). 
[9] Larson, Mildred L. Meaning-based translation: A guide to cross-language equivalence. Lanham, MD: University Press of America. (1984)

[10] Mildred L. Larson. Language Arts \& Disciplines. University Press of America. (1998)

[11] Manafi, Anari Salar. Accuracy, Clarity and Naturalness in Translation of Religious Texts. Translation Studies: Volume 2.St. Jerome Publishing Ltd. (2004).

[12]Maxwell, Joseph A. \& Mittapalli,Kavita. Explanatory Research. The SAGE Encyclopedia of Qualitative Research Methods. (2008)

[13] Miles, M., \& Huberman, A. Qualitative data analysis. Newbury park: Sage. (1984).

[14] Newmark, Peter. A Textbook of Translation. Pretince: Pretince Hall. (1988).

[15] Nida, Eugene A \& Taber, Charles R. The Theory and Practice of Translation. United Bible Society. (1964).

[16] Nida, E. A. Toward a Science of Translation. Leiden: E. J. Brill. (1964).

[17] Oshima, Alice., \& Hogue. Introduction to Academic Writing. New York: Addition Wesley Longman. (1997).

[18] Panou, Despoina. Equivalence in Translation Theories: A Critical Evaluation. Findland: Academy Publisher. (2013).

[19] Priono, Oni. The Naturalnessin Translating a Song Lyric 'Welcome to the Black Parade' by the Third Grade Students of SMA Negeri 1 Sangasanga in 2008/2009. Samarinda: FKIP Unmul Unpublished Thesis. (2009).

[20] Puspitanegara, Aulia. Text Translation Errors Done by the Seventh Semester Students of the English Department Mulawarman University in Academic Year 2008/2009. Samarinda: FKIP Unmul Unpublished Thesis. (2012).

[21] Saldana, J. The Coding Manual for Qualitative Researchers. London: Sage Pub Ltd. (2009).

[22] Savory, Theodore. The Art of Translation. London: Jonathan Cape. (1969)

[23] Sinaga, Diaz Marminus. The Ability of Translating Narrative English Text into Indonesian of the Sixth Semester Students of English Department Mulawarman University in Academic Year 2011/2012. Samarinda: FKIP Unmul Unpublished Thesis. (2012).

[24] Sugiyono. Metode Penelitian Administrasi. Bandung: Alfabeta. (2003).

[25] Suryawinata, Zuchridin., \& Hariyanto, Sugeng. Translation (Bahasan Teori dan Penuntun Praktis Menerjemahkan). Yogyakarta: Penerbit Kanisius. (2003).

[26] Susilo. Metode Penelitian Bidang Pendidikan: Kuantitatif, Kualitatif, Campuran. Yogyakarta: Kanwa Publisher. (2013).

[27] Xin, Li. An Investigation on Grammatical and Lexical Problems in the English-Chinese Document Translation in the United Nations. University of Queensland. (2010)

[28] http://www.britishcouncil.org/map_of_countries_where_english_is_an_official _language.pdf [online] last accessed on February 012019

[29] https://www.thejakartapost.com/news/2019/02/03/kpk-investigators-attacked-while-onduty.html last accessed on February 042019

[30] http://www.colorincolorado.org/article/using-cognates-develop-comprehension-english last accessed on January 282019 